\title{
In vitro modulation of MMP-2 and MMP-9 in human cervical and ovarian cancer cell lines by cytokines, inducers and inhibitors
}

\author{
M.W. ROOMI, J.C. MONTERREY, T. KALINOVSKY, M. RATH and A. NIEDZWIECKI \\ Dr Rath Research Institute, 1260 Memorex Drive, Santa Clara, CA 95050, USA
}

Received October 27, 2009; Accepted December 4, 2009

DOI: 10.3892/or_00000675

\begin{abstract}
Matrix metalloproteinases (MMPs) secreted by cervical and ovarian cancer, especially MMP-2 and MMP-9, play crucial roles in tumor invasion and metastasis. We examined the effect of cytokines, mitogens, inducers and inhibitors on MMP-2 and MMP-9 expression in cervical and ovarian cancer cell lines. Human cervical (HeLa and DoTc24510) and ovarian (SK-OV-3) cell lines were cultured in appropriate media. At near confluence, the cells were washed with PBS and incubated in serum-free medium with various concentrations of several cytokines, mitogens and inhibitors. After $24 \mathrm{~h}$ the media were removed and analyzed for MMP-2 and MMP-9 by gelatinase zymography and quantitated by densitometry. HeLa and SK-OV-3 cell lines expressed MMP-2 whereas DoTc2-4510 cells expressed MMP-9. Treatment of cervical cancer cell lines (HeLa and DoTc2-4510) with PMA had no effect on MMP-2 expression and a moderate stimulatory effect in ovarian cancer cell line SK-OV-3. MMP-9 was stimulated by phorbol 12-myristate 13 -acetate in HeLa cells and enhanced in DoTc2-4510. Tumor necrosis factor- $\alpha$ and interleukin-1ß, had slight inhibitory effect on HeLa cell expression of MMP-2 while lipopolysaccharide stimulated MMP-2 in HeLa cells. Doxycycline, epigallocatechin gallate, a nutrient mixture, actinomycin-D, cyclohexamide, retinoic acid and dexamethasone inhibited MMP-2 in HeLa and SK-OV-3 cell lines and inhibited MMP-9 in DoTc2-4510. Our results show that cytokines, mitogens, inducers and inhibitors have an up or down regulatory effect on MMP-2 and MMP-9 expression in ovarian and cervical cancer cell lines, suggesting these agents may be effective strategies to treat these cancers.
\end{abstract}

\section{Introduction}

Cervical cancer is the fifth most common malignant neoplasm worldwide and the second most common in less developed

Correspondence to: Dr Aleksandra Niedzwiecki, 1260 Memorex Drive, Santa Clara, CA 95050, USA

E-mail: author@drrath.com

Key words: matrix metalloproteinases, SK-OV-3, HeLa, DoTc24510, cytokines, inducers, inhibitors countries (1). The death rate for cervical cancer, which was once one of the most common causes of cancer death for American women, declined by $74 \%$ between 1955 and 1992, mainly due to the increased use of the Pap test (2). The American Cancer Society estimates that in 2009, 11,270 cases of invasive cervical cancer will be diagnosed in the United States and 4,070 women will die from cervical cancer (2). Cervical cancer develops slowly, taking 10-15 years to develop into cancer, starting with a pre-cancerous condition called dysplasia that can be detected by pap smears and is fully treatable. However, once the cancer has metastasized, patient outcome is poor. Epithelial ovarian carcinoma, which occurs mainly in post-menopausal women, is the leading cause of death from gynecological malignancy and the fifth most common cancer in the US (3). Since ovarian cancer often remains clinically silent, the majority of patients with ovarian carcinoma have advanced intraperitoneal metastatic disease at diagnosis, resulting in a poor prognosis. About $80 \%$ of ovarian cancer cases are diagnosed at an advanced stage after metastasis has occurred (3). Matrix metalloproteinase (MMP) expression has been shown to be linked to tumor invasion in many different tumors (4,5-10). In addition, clinical studies note the association of MMP expression with progression of cervical $(11,12)$ and ovarian $(13,14)$ cancer.

MMPs degrade various components of the extracellular matrix (ECM), including collagen, laminin, fibronectin, vitronectin, elastin and proteoglycans. Since MMPs play a critical role in cancer invasion, migration metastasis and tumorigenesis, blocking tumor cell expression of MMPs can significantly reduce tumor invasion and metastasis $(5,6,15)$. Although there are five major classes of proteases, interest has been focused on type IV collagenases, MMP-2 (gelatinase A) and MMP-9 (gelatinase B), both of which cleave collagen IV, a major component of ECM and basement membrane. Most MMPs are secreted as zymogens and must be activated extracellularly. MMP-2 (72 kDa) and MMP-9 (92 kDa) are secreted in their latent zymogenic form and cleaved by other MMPs or proteases to yield the activated forms of 68,58 and $54 \mathrm{kDa}$ for MMP-2 and $94 \mathrm{kDa}$ for MMP-9. Many human tumors have been reported to be associated with increased expression of MMP-2 and MMP-9 (16-18) and tumor aggression has been found to significantly correlate with increased levels of MMP-2 and MMP-9 in many experimental and clinical studies (5-10).

MMP activity is regulated by, and dependent upon environmental influences from surrounding stroma, ECM proteins, systemic hormones and other factors $(17,19,20)$. A 
Table I. Quantitative densitometry results from the effects of inducers PMA, TNF- $\alpha$, IL-1ß and LPS on MMP-2 and MMP-9 expression in cervical and ovarian cancer cell lines.

\begin{tabular}{|c|c|c|c|c|c|c|}
\hline & \multicolumn{2}{|c|}{ Cervical cancer (HeLa) } & \multicolumn{2}{|c|}{ Cervical cancer (DoTc2-4510) } & \multicolumn{2}{|c|}{ Ovarian cancer (SK-OV-3) } \\
\hline & MMP-2 (\%) & MMP-9 (\%) & MMP-2 (\%) & MMP-9 (\%) & MMP-2 (\%) & MMP-9 (\%) \\
\hline \multicolumn{7}{|c|}{ PMA (ng/ml) } \\
\hline Control & 12.6 & 0.0 & 0 & 10.4 & 17.7 & 0 \\
\hline 10 & 12.1 & 10.5 & 0 & 19.4 & 22.3 & 0 \\
\hline 25 & 12.2 & 10.4 & 0 & 23.9 & 20.2 & 0 \\
\hline 50 & 12.2 & 10.3 & 0 & 24.3 & 19.1 & 0 \\
\hline 100 & 10.7 & 9.1 & 0 & 22.0 & 20.7 & 0 \\
\hline \multicolumn{7}{|c|}{$\mathrm{TNF}-\alpha(\mathrm{ng} / \mathrm{ml})$} \\
\hline Control & 15.9 & 0.0 & 0 & 12.9 & 19.2 & 0 \\
\hline 0.1 & 15.3 & 11.1 & 0 & 17.9 & 21.8 & 0 \\
\hline 1 & 15.0 & 14.2 & 0 & 19.1 & 25.9 & 0 \\
\hline 10 & 15.4 & 0.0 & 0 & 22.2 & 17.4 & 0 \\
\hline 25 & 13.1 & 0.0 & 0 & 27.9 & 15.7 & 0 \\
\hline \multicolumn{7}{|c|}{$\mathrm{IL}-1 ß(\mathrm{ng} / \mathrm{ml})$} \\
\hline Control & 25.3 & 0 & 0 & 17.3 & 19.3 & 0 \\
\hline 0.1 & 21.0 & 0 & 0 & 20.7 & 20.3 & 0 \\
\hline 1 & 21.1 & 0 & 0 & 26.5 & 18.6 & 0 \\
\hline 10 & 18.3 & & 0 & 24.6 & 19.4 & 0 \\
\hline 25 & 14.2 & 0 & 0 & 10.9 & 22.3 & 0 \\
\hline \multicolumn{7}{|c|}{ LPS $(\mu \mathrm{g} / \mathrm{ml})$} \\
\hline Control & 15.3 & 0 & 0 & 15.0 & 20.5 & 0 \\
\hline 10 & 16.1 & 1.7 & 0 & 20.3 & 18.5 & 0 \\
\hline 25 & 16.8 & 2.0 & 0 & 22.3 & 21.1 & 0 \\
\hline 50 & 20.3 & 2.2 & 0 & 21.4 & 20.3 & 0 \\
\hline 100 & 23.4 & 2.3 & 0 & 21.0 & 19.6 & 0 \\
\hline
\end{tabular}

variety of cytokines and growth factors, such as transforming growth factor (TGF- $\beta$ ), hepatocyte growth factor (HGF), epidermal growth factor (EGF) and tumor necrosis factor (TNF- $\alpha$ ) also control MMP activity $(21,22)$. One of the most potent inducers is the chemical agent phorbol 12-myristate 13-aceteate (PMA). In addition, activity of MMPs is regulated at multiple levels, including transcription, modulation of messenger RNA half-life (translation), secretion, localization, activation and inhibition (23).

In this study, we investigated the roles of cytokines, inducers and inhibitors in the regulation of MMP-2 and MMP-9 activities in two related female cancers, cervical and ovarian cancer.

\section{Materials and methods}

Materials. Human cervical cancer cell lines HeLa and DoTc2-4510 and ovarian cancer cell line SK-OV-3, along with their culture media MEM and McCoy, respectively, were obtained from ATCC. Antibiotics, penicillin and fetal bovine serum (FBS), were obtained from Gibco (BRL, Long Island, NY). Twenty-four-well tissue culture plates were obtained from Costar (Cambrdige, MA). Gelatinase zymography was performed in $10 \%$ Novex pre-cast SDS polyacrylamide gel (Invitrogen Inc.) with $0.1 \%$ gelatin in non-reducing conditions. Interleukin $1 \beta$ (IL-1ß), tumor necrosis factor- $\alpha$ (TNF- $\alpha$ ), PMA, lipopolysaccharide (LPS), doxycycline, epigallocatechin gallate (EGCG), cyclohexamide, actinomycin-D, retinoic acid and dexamethasone, were purchased from Sigma (St. Louis, MO). The nutrient mixture (NM), prepared by VitaTech (Hayward, CA) was composed of the following ingredients in the relative amounts indicated: Vitamin $\mathrm{C}$ (as ascorbic acid and as $\mathrm{Mg}, \mathrm{Ca}$, and palmitate ascorbate) $700 \mathrm{mg}$; L-lysine $1000 \mathrm{mg}$; L-proline $750 \mathrm{mg}$; L-arginine $500 \mathrm{mg}$; N-acetyl cysteine $200 \mathrm{mg}$; standardized green tea extract ( $80 \%$ polyphenol) $1000 \mathrm{mg}$; selenium $30 \mu \mathrm{g}$; copper $2 \mathrm{mg}$; manganese $1 \mathrm{mg}$. All other reagents used were of high quality and were obtained from Sigma, unless otherwise indicated.

Cell cultures. Human cervical cancer cell lines HeLa and DoTc2-4510 were grown in MEM and ovarian cancer cell line SK-OV-3 in McCoy medium supplemented with $10 \%$ FBS, penicillin (100 units/ml) and streptomycin $(100 \mu \mathrm{g} / \mathrm{ml})$ in 24-well tissue culture plates. The cells were plated at a density of $1 \times 10^{5}$ cells $/ \mathrm{ml}$ and maintained in a humidified atmosphere 

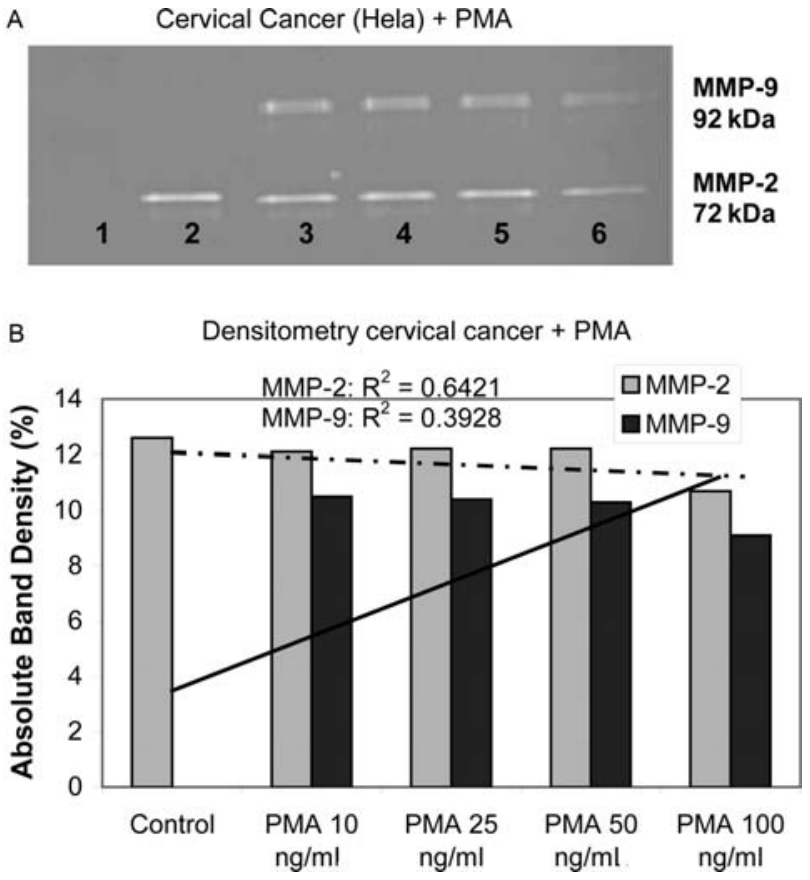

Figure 1. Effect of PMA on MMP expression in cervical cancer cell line HeLa. (A) Gelatinase zymogram of HeLa cells showing induction of MMP-9 expression after PMA treatment. Untreated HeLa cells expressed only MMP-2. PMA induced MMP-9 in a dose-dependent manner but had no effect on MMP-2 expression. 1, Makers; 2, Control; 3-6, 10, 25, 50, 100 ng/ml PMA. (B) Quantitative densitometric analysis of MMP expression of HeLa gelatinase zymogram. MMP expression is reported relative to the band density of MMP- 2 in the control lane. Trend analysis: $\mathrm{R}^{2}=0.6421$ MMP- $2 ; \mathrm{R}^{2}=0.3928$ MMP-9.

of $5 \% \mathrm{CO}_{2}$ in air at $37^{\circ} \mathrm{C}$ until confluent. Serum-supplemented medium was removed and cell monolayer was washed twice with PBS and once with serum-free media. The cells were then incubated in $0.5 \mathrm{ml}$ of serum-free medium with various cytokines, mitogens, inducers and inhibitors in triplicates, as indicated: PMA $(10,25,50,100 \mathrm{ng} / \mathrm{ml})$; TNF- $\alpha(0.1,1,10$, $25 \mathrm{ng} / \mathrm{ml})$; IL-ß $(0.1,1,10,25 \mathrm{ng} / \mathrm{ml})$; LPS $(10,25,50,100$ $\mu \mathrm{g} / \mathrm{ml})$; EGCG $(10,25,50,100 \mu \mathrm{M})$ without and with PMA; doxycycline $(10,25,50,100 \mu \mathrm{M})$ without and with PMA; $\mathrm{NM}(10,50,100,500,1000 \mu \mathrm{g} / \mathrm{ml})$ without and with PMA; retinoic acid $(50 \mu \mathrm{M})$; dexamethasone $(50 \mu \mathrm{M})$; actinomycin-D (2 and $4 \mu \mathrm{g} / \mathrm{ml})$; and cyclohexamide ( 2 and $4 \mu \mathrm{g} / \mathrm{ml})$. The plates were then returned the to the incubator. The conditioned medium from each treatment was collected separately, pooled, and centrifuged at $4^{\circ} \mathrm{C}$ for $10 \mathrm{~min}$ at $3,000 \mathrm{rpm}$ to remove cells and cell debris. The clear supernatant was collected and used for gelatinase zymography, as described below.

Gelatinase zymography. Gelatinase zymography was utilized because of its high sensitivity to gelatinolytic enzymatic activity and ability to detect both pro and active forms of MMP-2 and MMP-9. Upon renaturation of the enzyme, the gelatinases digest the gelatin in the gel and reveal clear bands against an intensely stained background. Gelatinase zymography was performed in $10 \%$ Novex pre-cast SDS polyacrylamide gel in the presence of $0.1 \%$ gelatin under non-reducing conditions. Culture media $(20 \mu 1)$ were mixed with sample buffer and loaded for SDS-PAGE with tris glycine
A
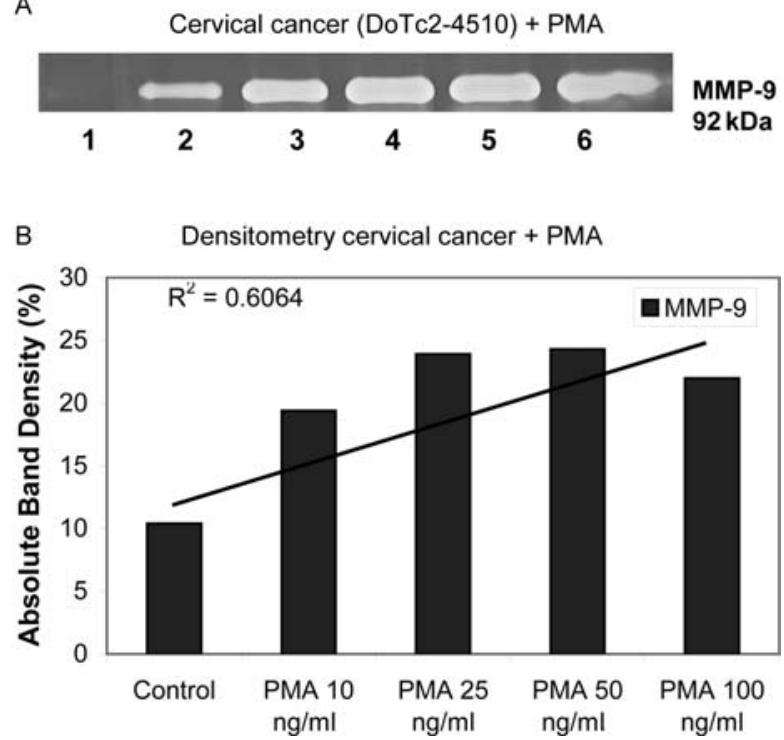

Figure 2. Effect of PMA treatment on MMP expression in cervical cancer cell line DoTc2-4510. (A) Gelatinase zymogram of DoTc2-4510 cells showing dose-dependent stimulation of MMP-9 expression with PMA treatment. DoTc2-4510 cells only expressed MMP-9. MMP-2 expression was not induced with PMA treatment. 1, Makers; 2, Control; 3-6, 10, 25, 50, $100 \mathrm{ng} / \mathrm{ml}$ PMA. (B) Quantitative densitometric analysis of MMP expression of DoTc2-4510 gelatinase zymogram. MMP expression is reported relative to the band density of MMP-9 in the control lane. Trend analysis: $\mathrm{R}^{2}=0.6064$.

SDS buffer, as suggested by the manufacturer (Novex). Samples were not boiled before electrophoresis. Following electrophoresis the gels were washed twice in $2.5 \%$ Triton $\mathrm{X}-100$ for $30 \mathrm{~min}$ at room temperature to remove SDS. The gels were then incubated at $37^{\circ} \mathrm{C}$ overnight in substrate buffer containing $50 \mathrm{mM}$ Tris- $\mathrm{HCl}$ and $10 \mathrm{mM} \mathrm{CaCl}_{2}$ at $\mathrm{pH} 8.0$ and stained with $0.5 \%$ Coomassie Blue R250 in $50 \%$ methanol and $10 \%$ glacial acetic acid for $30 \mathrm{~min}$ and destained. Protein standards were run concurrently and approximate molecular weights were determined by plotting the relative mobilities of known proteins. Gelatinase zymograms were scanned using CanoScan 9950F Canon scanner at 300 dpi. The intensity of the bands was evaluated using the pixel-based densitometer program Un-Scan-It, Version 5.1, 32-bit, by Silk Scientific Corporation (P.O. Box 533, Orem, UT 84059, USA), at a resolution of 1 Scanner Unit (1/100 of an inch for an image that was scanned at $100 \mathrm{dpi}$ ).

\section{Results}

Effect of inducers PMA, TNF- $\alpha, I L-1 \beta$ and LPS on MMP-2 and MMP-9 expression in cervical and ovarian cancer cell lines. Table I shows the quantitative densitometry results from the effects of inducers PMA, TNF- $\alpha$, IL-1ß and LPS on MMP-2 and MMP-9 expression in cervical and ovarian cancer cell lines (HeLa, DoTc2-4510 and SK-OV-3). As shown in Fig. 1A and B, PMA had no significant effect on HeLa cell expression of MMP-2, but stimulated MMP-9 expression in a dose-dependent manner (10-100 ng/ml). DoTc2-4510 showed no MMP-2 expression with or without PMA; however, expression of MMP-9 was stimulated with PMA treatment, as shown in Fig. 2A and B. SK-OV-3 showed 


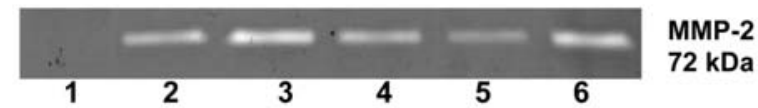

B

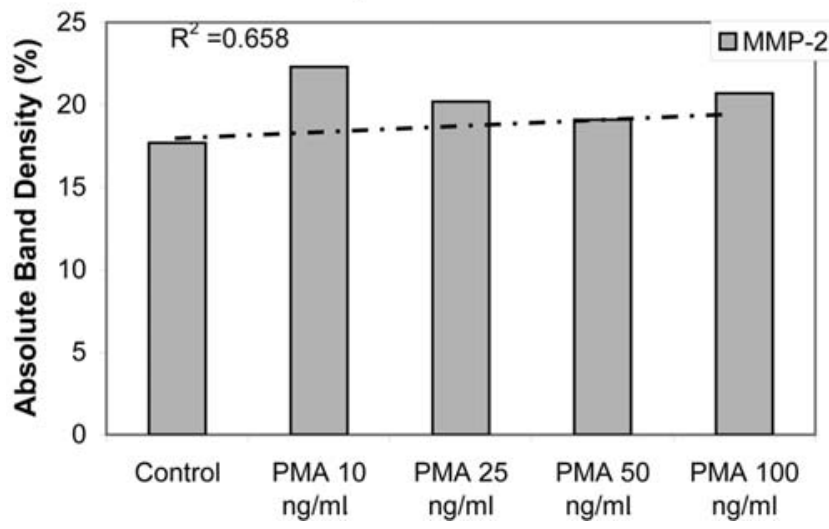

Figure 3. Effect of PMA treatment on MMP expression in ovarian cell line SK-OV-3. (A) Gelatinase zymogram of SK-OV-3 cells showing expression of MMP-2, which was neither induced nor inhibited by PMA treatment. PMA treatment did not induce MMP-9 expression. 1, Makers; 2, Control; 3-6, 10, 25, 50, $100 \mathrm{ng} / \mathrm{ml}$ PMA. (B) Quantitative densitometric analysis of MMP expression of SK-OV-3 gelatinase zymogram. MMP expression is reported relative to the band density of MMP-2 in the control lane. Trend analysis: $\mathrm{R}^{2}=0.658$.

a single band corresponding to MMP-2, which was not affected by PMA treatment (Fig. 3A and B). TNF- $\alpha$ had a stimulatory dose-dependent effect on MMP-9 in DoTc24510, did not affect MMP-2 expression in HeLa cells, and slightly stimulated MMP-2 expression in ovarian cancer cells SK-OV-3. IL-1ß stimulated MMP-9 in DoTc2-4510 cells at 0.1 and $1 \mathrm{ng} / \mathrm{ml}$, but had an inhibitory effect at 10 and $25 \mathrm{ng} / \mathrm{ml}$. IL-1ß had a dose-dependent inhibitory effect on MMP-2 in HeLa cells and no effect in SK-OV-3 cells. LPS showed a dose-dependent enhanced effect on MMP-2 and MMP-9 expression in HeLa cells and MMP-9 in DoTc2-4510, but no effect on MMP-2 in ovarian cancer cells.

Effect of inhibitors doxycycline and EGCG on MMP-2 and MMP-9 expression in cervical and ovarian cancer cell lines. Table II shows the quantitative densitometry results from the effects of inhibitors doxycycline and EGCG on MMP-2 and MMP-9 expression in untreated and PMA-treated cervical and ovarian cancer cell lines (HeLa, DoTc2-4510 and SK$\mathrm{OV}-3$ ). Doxycycline inhibited the expression of MMP-2 in HeLa (Fig. 4A and B) and SK-OV-3 cells (Fig. 6A and B), and the expression of MMP-9 in DoTc2-4510 (Fig. 5A and B) in a dose-dependent fashion. HeLa cells were most sensitive to doxycycline, followed by DoTc2-4510 and SK-OV-3. PMA-treated HeLa cells exposed to doxycycline (Fig. 4C and D) showed lower MMP-2 activity than cells not treated with PMA and dose-dependent inhibition with increasing doxycycline dose. PMA induced MMP-9 expression by HeLa cells that was inhibited in a dose-dependent manner with increased doxycycline. Doxycycline inhibited PMA-induced MMP-9 expression in DoTc2-4510 cells (Fig. 5C and D) and MMP-2 expression in SK-OV-3 cell lines (Fig. 6C and D) in a dose-dependent manner. Doxycycline inhibited the
A

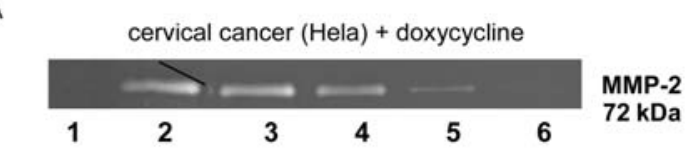

B Densitometry - cervical cancer Hela + doxycycline

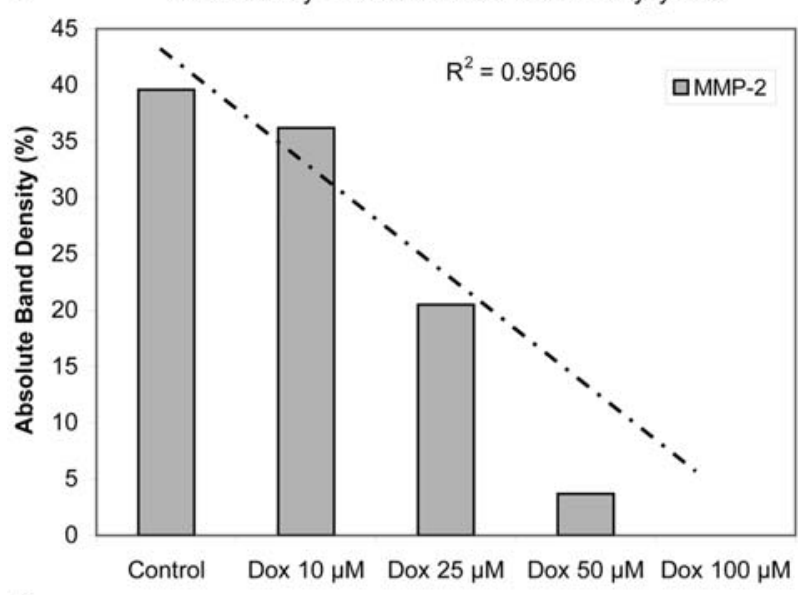

C

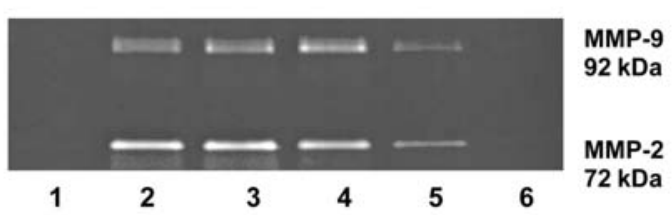

D

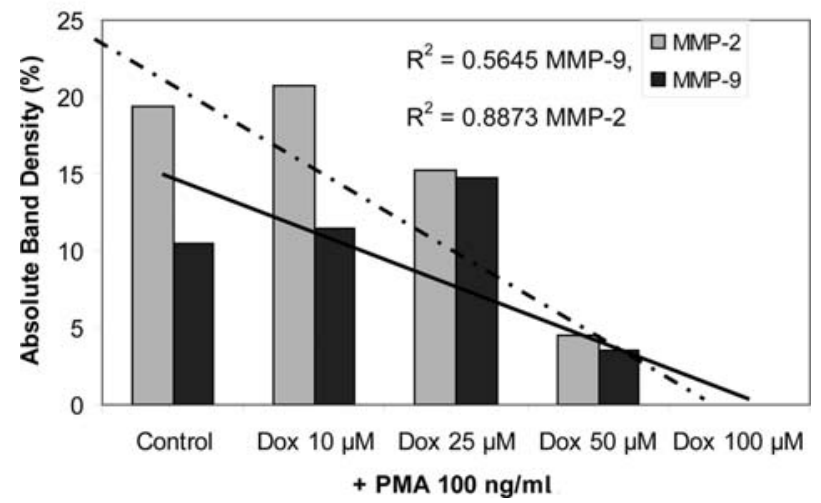

Figure 4. Effect of doxycycline on MMP expression in PMA (100 ng/ml)treated cervical cancer cell line HeLa. (A) Gelatinase zymogram of HeLa cells showing dose-dependent decrease of MMP-2 expression with doxycycline treatment. 1, Makers; 2, Control; 3-6, 10, 25, 50, $100 \mu \mathrm{M}$ doxycycline. (B) Quantitative densitometric analysis of MMP expression in doxycycline-treated HeLa cells. Trend analysis $\mathrm{R}^{2}=0.9506$. (C) Gelatinase zymogram of HeLa cells stimulated to express MMP-9 via PMA $(100 \mathrm{ng} / \mathrm{ml})$ showing a dose-dependent decrease of both MMP-2 and MMP-9 expression with increasing concentrations of doxycycline. 1, Makers; 2, Control; 3-6, 10, $25,50,100 \mu \mathrm{M}$ doxycycline. (D) Quantitative densitometric analysis of MMP expression in PMA-stimulated HeLa cells treated with doxycycline. MMP expression is reported relative to the band density of MMP-2 in the control lane. Trend analysis: $\mathrm{R}^{2}=0.5645 \mathrm{MMP}-9 ; \mathrm{R}^{2}=0.8873 \mathrm{MMP}-2$.

expression of MMP-2 in HeLa and SK-OV-3 cell lines equally. EGCG decreased both MMP-2 and MMP-9 expression in HeLa cells and completely abolished their expression at $50 \mu \mathrm{M}$ concentration. EGCG decreased MMP-9 expression in DoTc2-4510 and MMP-2 in ovarian cancer cell line SK-OV-3. Sensitivity to EGCG was greater in DoTc2-4510 cells, followed by HeLa and SK-OV-3 cells. 
Table II. Quantitative densitometry results from the effects of inhibitors doxycycline and EGCG on MMP-2 and MMP-9 expression in untreated and PMA-treated cervical and ovarian cancer cell lines.

\begin{tabular}{|c|c|c|c|c|c|c|}
\hline & \multicolumn{2}{|c|}{ Cervical cancer (HeLa) } & \multicolumn{2}{|c|}{ Cervical cancer (DoTc2-4510) } & \multicolumn{2}{|c|}{ Ovarian cancer (SK-OV-3) } \\
\hline & MMP-2 (\%) & MMP-9 (\%) & MMP-2 (\%) & MMP-9 (\%) & MMP-2 (\%) & MMP-9 (\%) \\
\hline \multicolumn{7}{|c|}{ Doxycycline $(\mu \mathrm{M})$} \\
\hline Control & 39.6 & 0 & 0 & 24.7 & 25 & 0 \\
\hline 10 & 36.2 & 0 & 0 & 22.9 & 22 & 0 \\
\hline 25 & 20.5 & 0 & 0 & 20.8 & 27 & 0 \\
\hline 50 & 3.7 & 0 & 0 & 18.9 & 16 & 0 \\
\hline 100 & 0.0 & 0 & 0 & 12.7 & 9 & 0 \\
\hline \multicolumn{7}{|c|}{ Doxycycline $(\mu \mathrm{M})$ with } \\
\hline \multicolumn{7}{|c|}{ PMA (200 ng/ml) } \\
\hline Control & 19.4 & 10.5 & 0 & 52.6 & 29.1 & 0 \\
\hline 10 & 20.7 & 11.5 & 0 & 30.0 & 26.6 & 0 \\
\hline 25 & 15.2 & 14.8 & 0 & 15.2 & 21.6 & 0 \\
\hline 50 & 4.5 & 3.5 & 0 & 2.2 & 17.2 & 0 \\
\hline 100 & 0.0 & 0.0 & 0 & 0.0 & 5.5 & 0 \\
\hline \multicolumn{7}{|c|}{$\mathrm{EGCG}(\mu \mathrm{M})$} \\
\hline Control & 39.0 & 0 & 0 & 78.4 & 38.0 & 0 \\
\hline 10 & 33.9 & 0 & 0 & 14.9 & 21.4 & 0 \\
\hline 25 & 27.1 & 0 & 0 & 4.2 & 19.8 & 0 \\
\hline 50 & 0.0 & 0 & 0 & 2.5 & 16.5 & 0 \\
\hline 100 & 0.0 & 0 & 0 & 0.0 & 4.3 & 0 \\
\hline \multicolumn{7}{|c|}{ EGCG $(\mu \mathrm{M})$ with } \\
\hline \multicolumn{7}{|c|}{ PMA (200 ng/ml) } \\
\hline Control & 35.9 & 20.0 & 0 & 45.9 & 32.4 & 0 \\
\hline 10 & 11.1 & 15.1 & 0 & 35.4 & 20.9 & 0 \\
\hline 25 & 5.1 & 10.8 & 0 & 15.4 & 13.2 & 0 \\
\hline 50 & 0.9 & 1.1 & 0 & 3.2 & 19.5 & 0 \\
\hline 100 & 0.0 & 0.0 & 0 & 0.2 & 14.1 & 0 \\
\hline \multicolumn{7}{|c|}{ Dexamethasone $(\mu \mathrm{M})$} \\
\hline Control & 62.7 & 0 & 0 & 100 & 82.5 & 0 \\
\hline 100 & 37.3 & 0 & 0 & 0 & 17.5 & 0 \\
\hline \multicolumn{7}{|c|}{ Actinomycin-D $(\mu \mathrm{g} / \mathrm{ml})$} \\
\hline Control & 63.0 & 0 & 0 & 52.4 & 36.5 & 0 \\
\hline 2 & 19.4 & 0 & 0 & 27.9 & 34.7 & 0 \\
\hline 4 & 17.6 & 0 & 0 & 19.7 & 28.8 & 0 \\
\hline \multicolumn{7}{|c|}{ Cyclohexamide $(\mu \mathrm{g} / \mathrm{ml})$} \\
\hline Control & 100 & 0 & 0 & 100 & 87.0 & 0 \\
\hline 2 & 0 & 0 & 0 & 0 & 7.7 & 0 \\
\hline 4 & 0 & 0 & 0 & 0 & 5.3 & 0 \\
\hline \multicolumn{7}{|c|}{ Retinoic Acid $(\mu \mathrm{M})$} \\
\hline Control & $\mathrm{x}$ & $\mathrm{x}$ & 0 & 100 & 89.0 & 0 \\
\hline 50 & $\mathrm{x}$ & $\mathrm{x}$ & 0 & 0 & 11.0 & 0 \\
\hline
\end{tabular}

Effect of inhibitors retinoic acid, dexamethasone, actinomycin-D and cyclohexamide, on MMP-2 and MMP-9 expression in cervical and ovarian cancer cell lines. Table II shows the quantitative densitometry results from the effects of inhibitors retinoic acid, dexamethasone, actinomycin-D and cyclohexamide on MMP-2 and MMP-9 expression in untreated and PMA-treated cervical and ovarian cancer cell lines (HeLa, DoTc2-4510, and SK-OV-3). Dexamethasone at 
A

Cervical cancer cell line DoTc2-4510 + doxycycline
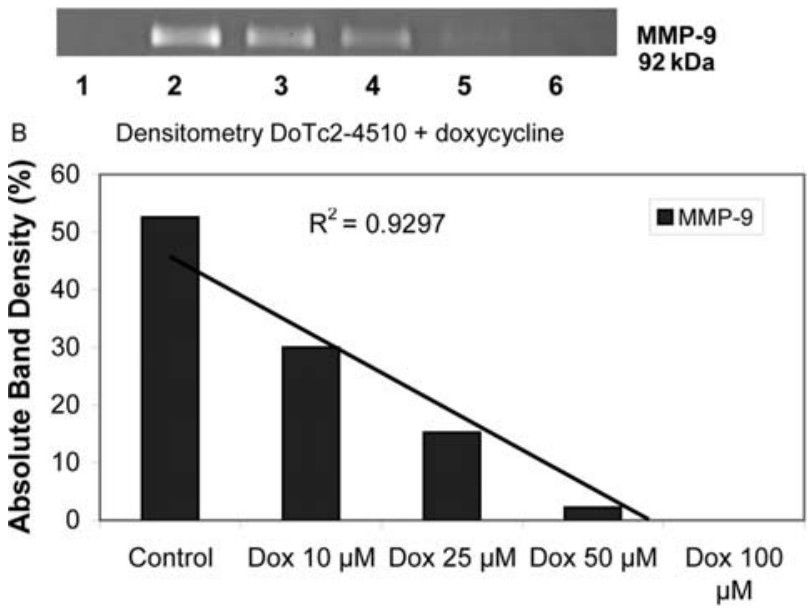

C

Cervical cancer cell line DoTc2-4510 + doxycycline+ PMA

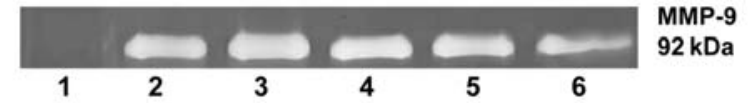

D Densitometry DoTc2-4510 + doxycycline+PMA

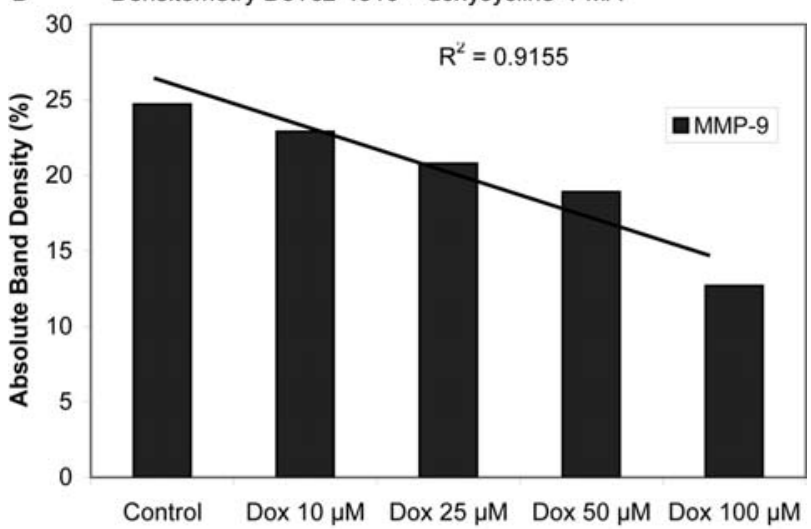

+ PMA $100 \mathrm{ng} / \mathrm{ml}$

Figure 5. Effect of doxycycline on MMP expression in PMA-treated cervica cancer cell line DoTc2-4510. (A) Gelatinase zymogram of DoTc2-4510 cells showing a dose-dependent decrease of MMP-9 expression with doxycycline treatment. 1, Makers; 2, Control; 3-6, 10, 25, 50, $100 \mu \mathrm{M}$ doxycycline. (B) Quantitative densitometric analysis of MMP-9 expression in doxycyclinetreated DoTc2-4510 cells. MMP expression is reported relative to the band density of MMP-9 in the control lane. Trend analysis: $R^{2}=0.9155$. (C) Gelatinase zymogram of DoTc2-4510 cells showing enhanced MMP-9 expression via PMA $(100 \mathrm{ng} / \mathrm{ml})$ treatment and dose-dependent decrease of MMP-9 expression with increasing concentrations of doxycycline. 1, Makers; 2, Control; 3-6, 10, 25, 50, $100 \mu \mathrm{M}$ doxycycline. (D) Quantitative densitometric analysis of MMP-9 expression in PMA stimulated DoTc2-4510 cells treated with doxycycline. Trend analysis: $\mathrm{R}^{2}=0.9297$.

$100 \mu \mathrm{M}$ inhibited the expression of MMP-2 in HeLa cells by $40 \%$ of control level and completely blocked MMP-9 expression in DoTc2-4510 cells. In SK-OV-3, MMP-2 expression was decreased by $79 \%$ of the control at a concentration of $100 \mu \mathrm{M}$ dexamethasone. Retinoic acid, on the other hand, abolished MMP-9 activity in DoTc2-4510 and reduced MMP-9 expression by $12 \%$ in SK-OV-3. Actinomycin-D at $4 \mu \mathrm{g} / \mathrm{ml}$ inhibited the expression of MMP-2 in HeLa to $28 \%$ of control, MMP-9 in DoTc2-4510 to $38 \%$ of control and MMP-2 in ovarian cancer cell line SK-OV-3 to $79 \%$ of control. Cyclohexamide, at concentrations 2 and $4 \mu \mathrm{g} /$ $\mathrm{ml}$ completely abolished the expression of MMP-2 in HeLa
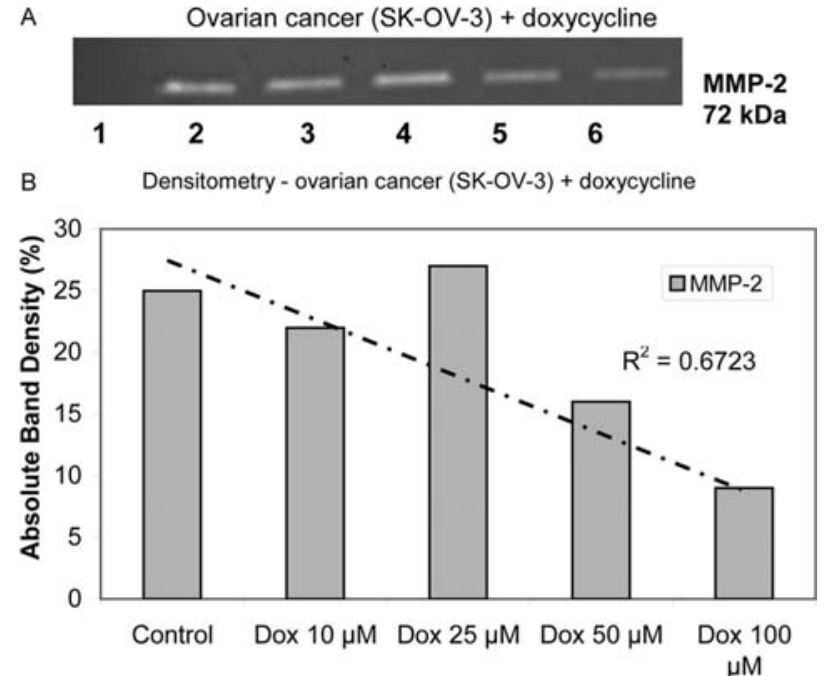

C
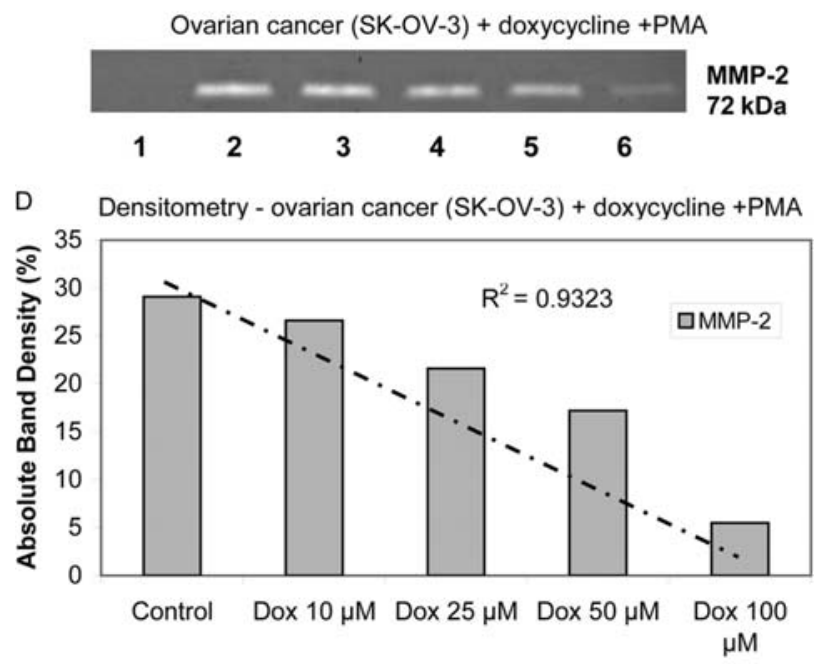

+PMA $100 \mathrm{ng} / \mathrm{ml}$

Figure 6. Effect of doxycycline on MMP expression in PMA-treated and untreated ovarian cancer cell line SK-OV-3. (A) Gelatinase zymogram of SK-OV-3 cells showing dose-dependent decrease of MMP-2 expression with doxycycline treatment. 1, Makers; 2, Control; 3-6, 10, 25, 50, $100 \mu \mathrm{M}$ doxycycline. (B) Quantitative densitometric analysis of MMP-2 expression in doxycycline treated SK-OV-3 cells. Trend analysis: $\mathrm{R}^{2}=0.6723$. (C) Gelatinase zymogram of PMA-treated (100 ng/ml) SK-OV-3 cells showing no effect of PMA on the dose-dependent decrease of MMP-2 expression via doxycycline treatment. 1, Makers; 2, Control; 3-6, 10, 25, 50, $100 \mu \mathrm{M}$ doxycycline. (D) Quantitative densitometric analysis of MMP-2 expression in SK-OV-3 cells treated with PMA and doxycycline. Trend analysis: $\mathrm{R}^{2}=0.9323$.

cells, MMP-9 in DoTc2-4510 cells and MMP-2 to 10 and 6\% of the control level in SK-OV-3. Retinoic acid at $50 \mu \mathrm{M}$ abolished MMP-9 expression by DoTc2-4510 cells and inhibited MMP-2 expression of SK-OV-3 cells to $12 \%$ of the control value.

Effect of the nutrient mixture (NM) on MMP-2 and MMP-9 expression in cervical and ovarian cancer cell lines. As shown in Table III and Figs. 7-9, NM had a dose-dependent inhibitory effect on all the cell lines. NM inhibited MMP-2 expression in HeLa cells in unstimulated conditioned media (Fig. 7A and B) and MMP-2 and MMP-9 in PMA-treated 


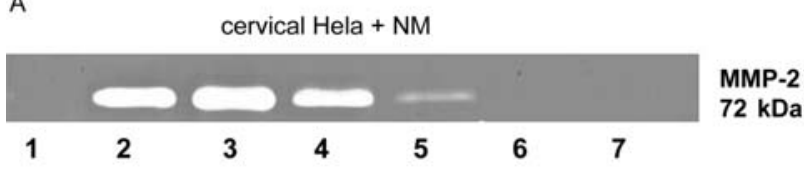

B

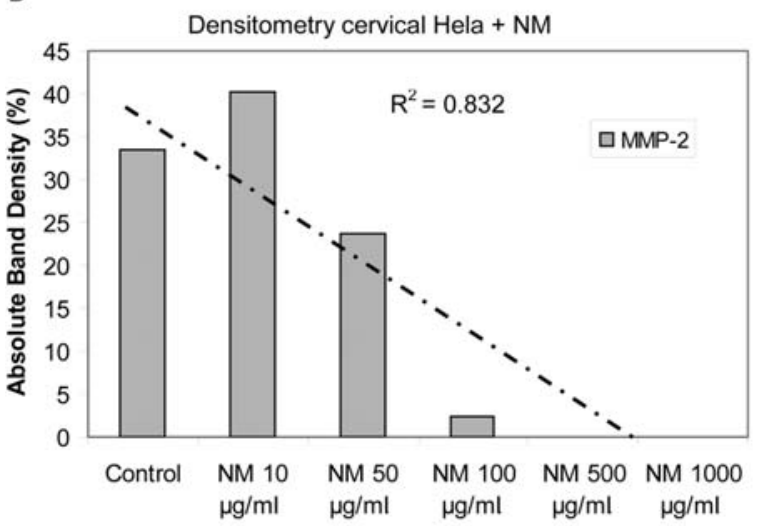

C
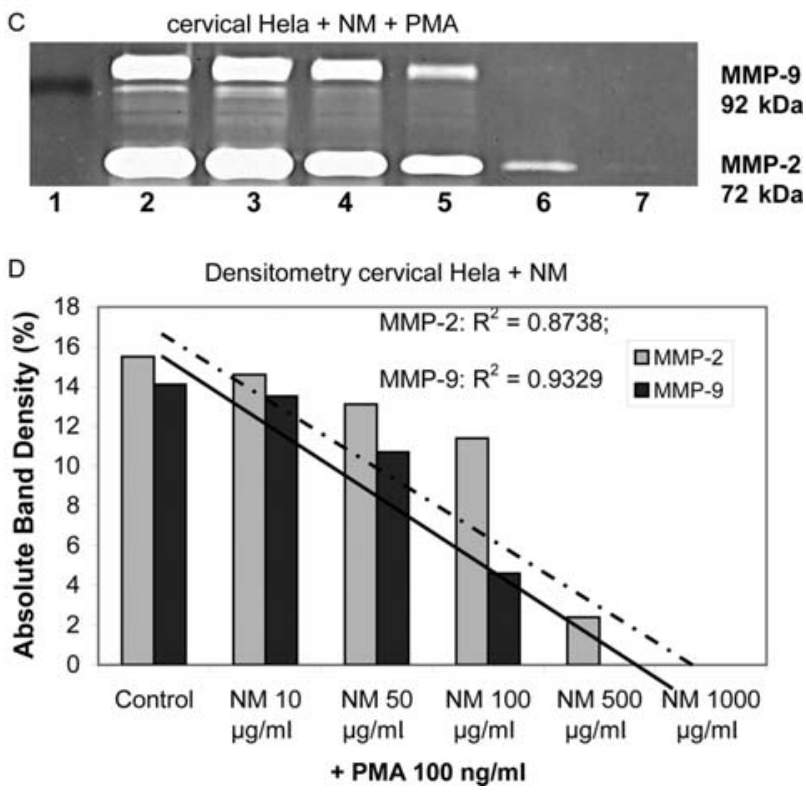

Figure 7. Effect of the nutrient mixture on MMP expression in PMA-treated and untreated cervical cell Line HeLa. (A) Gelatinase zymogram showing dose-dependent decrease of MMP-2 expression by HeLa cells with NM treatment. 1, Makers; 2, Control; 3-7, 10, 50, 100, 500, $1000 \mu \mathrm{g} / \mathrm{ml} \mathrm{NM.} \mathrm{(B)}$ Quantitative densitometric analysis of MMP-2 expression by HeLa cells treated with NM. Trend analysis: $\mathrm{R}^{2}=0.832$. (C) Gelatinase zymogram of PMA (100 ng/ml)-treated HeLa cells showing induction of MMP-9 but no effect on MMP-2 expression and dose-dependent decrease in MMP-2 and MMP-9 expression with NM treatment. 1, Makers; 2, Control; 3-7, 10, 50 , $100,500,1000 \mu \mathrm{g} / \mathrm{ml} \mathrm{NM}$. (D) Quantitative densitometric analysis of MMP-2 and MMP-9 expression in HeLa cells treated with PMA and the nutrient mixture. Trend analysis: $\mathrm{R}^{2}=0.8738$ MMP-2; $\mathrm{R}^{2}=0.9329$ MMP-9.

conditioned media (Fig. 7C and D) in a dose-dependent fashion, with complete blockage of MMP expression at 500 $\mu \mathrm{g} / \mathrm{ml}$. DoTc2-4510 showed MMP-9 expression (Fig. 8A and B), which was further enhanced by PMA (Fig. 8C and D); NM inhibited MMP-9 in a dose-dependent fashion, virtually abolishing MMP-9 at $500 \mu \mathrm{g} / \mathrm{ml}$. Ovarian cancer cell MMP-2 expression was unaffected by PMA treatment; NM inhibited MMP-2 expression in a dose-dependent manner with total blockage at $50 \mu \mathrm{g} / \mathrm{ml} \mathrm{NM}$ (Fig. 9A and D).
A

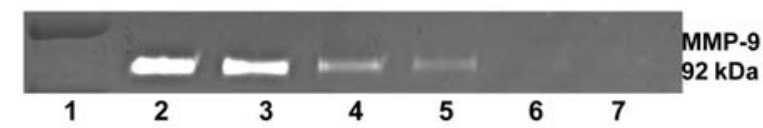

B

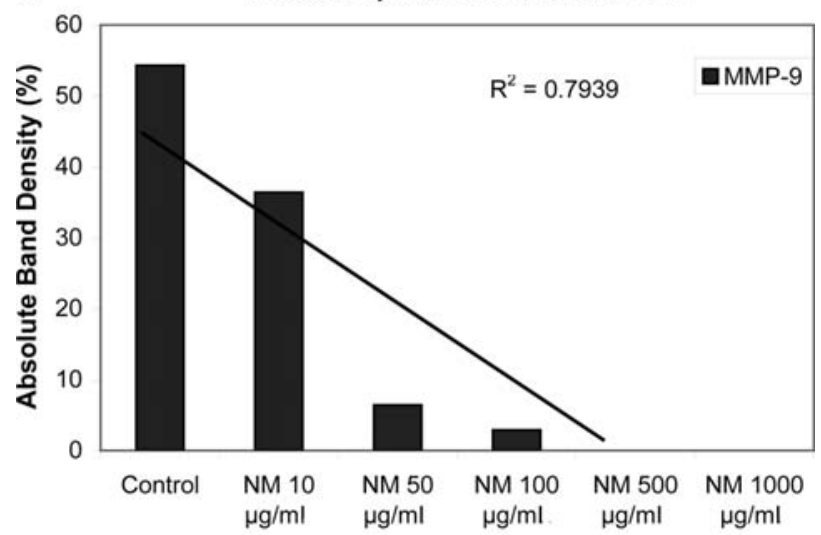

C

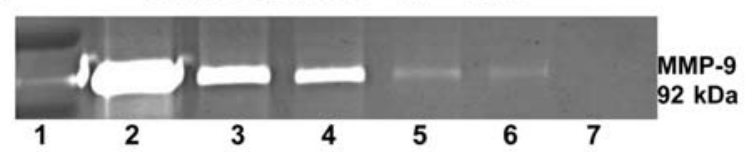

D

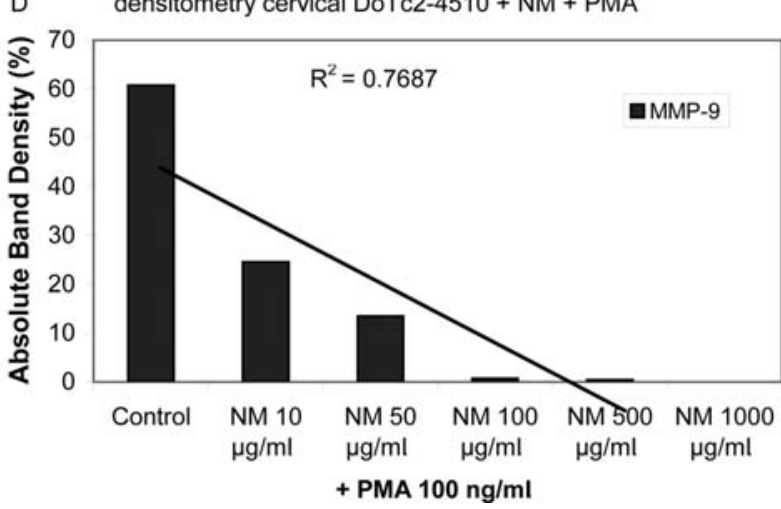

Figure 8. Effect of the nutrient mixture on MMP expression in PMA-treated and untreated cervical cell line DoTc2-4510. (A) Gelatinase zymogram of DoTc2-4510 cells showing dose-dependent decrease of MMP-9 expression with NM treatment. 1, Makers; 2, Control; 3-7, 10, 50, 100, 500, $1000 \mu \mathrm{g} / \mathrm{ml}$ NM. (B) Quantitative densitometric analysis of MMP-9 expression in DoTc24510 cells treated with NM. Trend analysis: $\mathrm{R}^{2}=0.7939$. (C) Gelatinase zymogram of PMA $(100 \mathrm{ng} / \mathrm{ml})$-treated DoTc2-4510 cells showing enhanced MMP-9 expression with PMA and dose-dependent decrease of MMP-9 with increasing concentration of NM. 1, Makers; 2, Control; 3-7, 10 , 50, 100, 500, $1000 \mu \mathrm{g} / \mathrm{ml} \mathrm{NM}$. (D) Quantitative densitometric analysis of MMP-9 expression in DoTc2-4510 cells treated with PMA and NM. Trend analysis: $\mathrm{R}^{2}=0.7687$.

\section{Discussion}

Experimental and clinical studies have shown a correlation between increased MMPs and tumor progression and metastasis (5-10). Thus, knowledge of MMP regulation is of great importance for developing therapeutic strategies. MMP expression is regulated at both pre and post-transcriptional levels. A number of extracellular factors, including cytokines, growth factors, cell contact with ECM, and inducers and 
Table III. The dose-dependent inhibitory effect of the nutrient mixture on the cell lines.

\begin{tabular}{|c|c|c|c|c|c|c|}
\hline & \multicolumn{2}{|c|}{ Cervical cancer $(\mathrm{HeLa})$} & \multicolumn{2}{|c|}{ Cervical cancer (DoTc2-4510) } & \multicolumn{2}{|c|}{ Ovarian cancer (SK-OV-3) } \\
\hline & MMP-2 (\%) & MMP-9 (\%) & MMP-2 (\%) & MMP-9 (\%) & MMP-2 (\%) & MMP-9 (\%) \\
\hline \multicolumn{7}{|c|}{ Nutrient mixture $(\mathrm{NM})(\mu \mathrm{g} / \mathrm{ml})$} \\
\hline Control & 33.5 & 0.0 & 0 & 54.3 & 70.9 & 0 \\
\hline 10 & 40.2 & 0.0 & 0 & 36.4 & 29.1 & 0 \\
\hline 50 & 23.6 & 0.0 & 0 & 6.4 & 0.0 & 0 \\
\hline 100 & 2.5 & 0.0 & 0 & 2.9 & 0.0 & 0 \\
\hline 500 & 0.0 & 0.0 & 0 & 0.0 & 0.0 & 0 \\
\hline 1000 & 0.0 & 0.0 & 0 & 0.0 & 0.0 & 0 \\
\hline \multicolumn{7}{|c|}{$\begin{array}{l}\text { Nutrient mixture }(\mathrm{NM})(\mu \mathrm{g} / \mathrm{ml}) \\
\text { with PMA }(200 \mathrm{ng} / \mathrm{ml})\end{array}$} \\
\hline Control & 15.5 & 14.1 & 0 & 60.8 & 71.8 & 0 \\
\hline 10 & 14.6 & 13.5 & 0 & 24.6 & 28.2 & 0 \\
\hline 50 & 13.1 & 10.7 & 0 & 13.5 & 0.0 & 0 \\
\hline 100 & 11.4 & 4.6 & 0 & 0.7 & 0.0 & 0 \\
\hline 500 & 2.4 & 0.0 & 0 & 0.4 & 0.0 & 0 \\
\hline 1000 & 0.0 & 0.0 & 0 & 0.0 & 0.0 & 0 \\
\hline
\end{tabular}

inhibitors, have been implicated in the regulation of MMP expression in different types of tumor cells $(24,25)$.

In this study, we compared MMP secretion patterns by cytokines, PMA and LPS in two related human cancers, cervical and ovarian cancer. In addition, we investigated the effect of inhibitors doxycycline and EGCG and others, such as dexamethasone, retinoic acid and agents that affect transcription and translation levels, such as actinomycin-D and cyclohexamide. Furthermore, we tested a nutrition mixture that had inhibitory effects on MMP-2 and MMP-9 expression. Normal and cancerous ovarian and cervical cells produce immunomodulatory cytokines; however cytokine expression patterns change after malignant transformation $(26,27)$. We chose cervical and ovarian cancer cell lines that express MMP-2 and MMP-9 to different extents. MMP-9 mRNA and protein expression have been shown to be significantly elevated in tumor and stromal cells of invasive squamous cell carcinoma of the uterine cervix (28). MMP-9 was also reported to be significantly associated with nodal metastasis of cervical cancer (13). Of interest, Torng et al report that though tumor MMP-2 levels are associated with poor prognosis of ovarian cancer, stromal MMP-2 levels in epithelial ovarian carcinoma were significantly associated with recurrence-free survival (14).

We found that cervical cancer cell line HeLa and ovarian cancer cell line SK-OV-3 normally expressed only MMP-2, whereas DoTc2-4510 normally expressed only MMP-9. Treatment of cervical cancer cell lines (HeLa and DoTc2-4510) with PMA had no effect on MMP-2 expression; however, MMP-2 was slightly stimulated by PMA in SK-OV-3 cells. MMP-9 was stimulated by PMA in HeLa cells at $10 \mathrm{ng} / \mathrm{ml}$ and this upregulated level of expression was maintained with increasing doses of PMA. PMA also enhanced MMP-9 expression in DoTc2-4510. However, MMP-9 expression by SK-OV-3 was not induced by any of the inducers tested. TNF- $\alpha$ had no effect on MMP-2 expression in HeLa cells, but slightly stimulated MMP-9 expression in HeLa cells and had a dose-dependent stimulatory effect on MMP-9 in DoTc2-4510. TNF- $\alpha$ had a slight stimulatory effect on MMP-2 secretion by SK-OV-3 cells at lower concentrations $(0.1-1 \mathrm{ng} / \mathrm{ml})$ and inhibition at $10-25 \mathrm{ng} / \mathrm{ml}$. IL-1ß had an inhibitory effect in HeLa cell MMP-2 expression and a stimulatory effect on MMP-9 in DoTc2-4510. LPS had a stimulatory effect on both MMP-2 and MMP-9 in HeLa cells and enhanced MMP-9 expression in DoTc2-4510 cells. However, IL-1ß and LPS had no significant effect on MMP-2 secretion by SK-OV-3 cells.

Doxycycline and EGCG, without and with PMA, inhibited the expression of MMP-2 and MMP-9 expression in a dosedependent fashion in HeLa cells, whereas MMP-9 was inhibited in DoTc2-4510 and MMP-2 in SK-OV-3. Sensitivity of inhibitors (decreasing magnitude of MMP-2 and MMP-9 expression) occurred in the following manner: DoTc2$4510>\mathrm{HeLa}>\mathrm{SK}-\mathrm{OV}-3$. In contrast, sensitivity to actinomycin-D was found to follow a different sequence: HeLa $>$ DoTc2-4510>SK-OV-3. The nutrition mixture, without and with PMA, decreased MMP-2 and MMP-9 expression in a dose-dependent fashion in HeLa cells and induced a significant decrease of MMP-9 expression in DoTc2-4510. It exhibited a much higher inhibitory effect on MMP-2 expression by SK-OV-3 than by HeLa or inhibition of MMP-9 in DoTc2-4510.

The nutrition mixture studied, which contains lysine, proline, ascorbic acid and green tea extract among other micronutrients, has been shown to have anti-tumor and antiinvasive potential in vivo (29) and in vitro (30). In this study, NM, without and with PMA, showed a dose-dependent decrease of MMP-2 and MMP-9 in the cancer cell lines tested. 
A

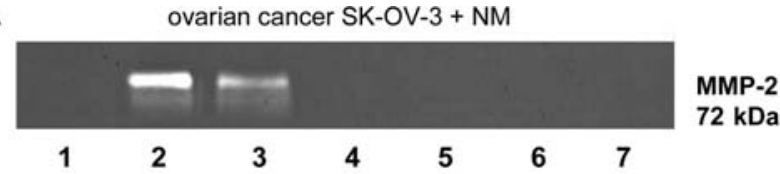

B Densitometry ovarian cancer SK-OV-3 + NM

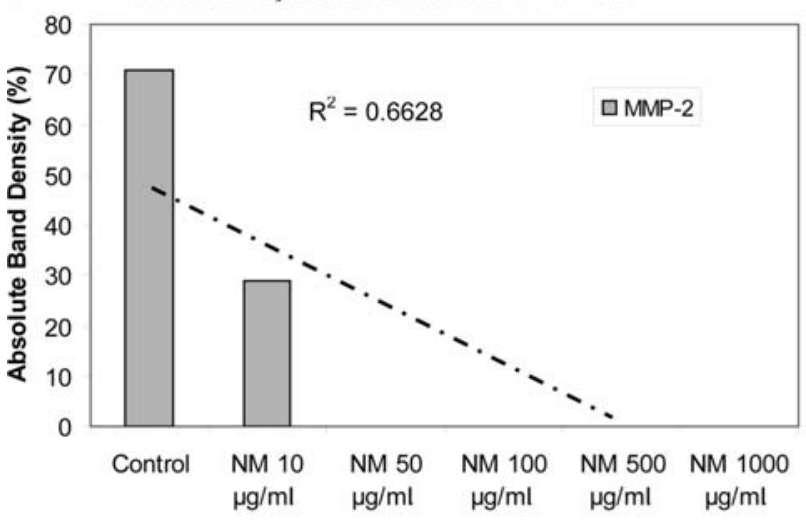

C

ovarian cancer SK-OV-3 + NM + PMA
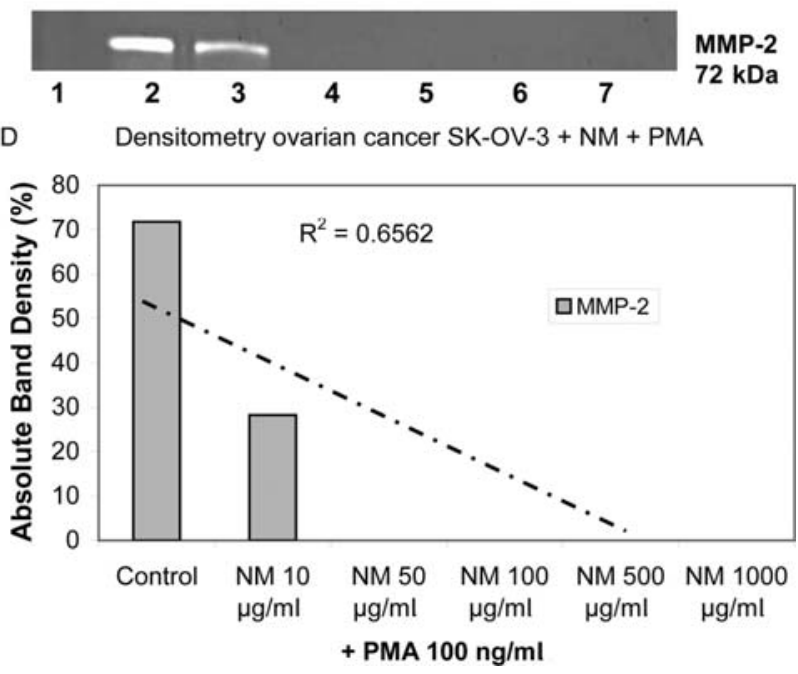

Figure 9. Effect of the nutrient mixture on MMP expression in PMA-treated and untreated ovarian cell line SK-OV-3. (A) Gelatinase zymogram of SKOV-3 cells showing dose-dependent decrease of MMP-2 expression with NM treatment. MMP-2 expression is completely inhibited at $50 \mu \mathrm{g} / \mathrm{ml} \mathrm{NM}$ 1, Makers; 2, Control; 3-7, 10, 50, 100, 500, $1000 \mu \mathrm{g} / \mathrm{ml} \mathrm{NM.} \mathrm{(B)}$ Quantitative densitometric analysis of MMP-2 expression in SK-OV-3 cells treated with NM. Trend analysis: $\mathrm{R}^{2}=0.6628$. (C) Gelatinase zymogram of PMA-treated SK-OV-3 cells showing dose-dependent decrease of MMP-2 with increasing NM concentration. 1, Makers; 2, Control; 3-7, 10, 50, 100 , $500,1000 \mu \mathrm{g} / \mathrm{ml} \mathrm{NM}$. (D) Quantitative densitometric analysis of MMP-2 expression in SK-OV-3 cells treated with PMA and the nutrient mixture. Trend analysis: $\mathrm{R}^{2}=0.6562$.

Of interest, in previous studies we found that NM had slight anti-proliferative effect on ovarian cancer cells SK-OV-3 cells but significant dose-dependent inhibition of Matrigel invasion of SK-OV-3 cells (31). In HeLa and DoTc2 4510 cells, NM had significant anti-proliferative effect as well as significant inhibition of Matrigel invasion (30).

We designed NM by focusing on physiological targets in cancer progression and metastasis, such as ECM integrity and MMP activity. Adequate supplies of ascorbic acid, lysine and proline to ensure proper synthesis and hydroxylation of collagen fibers are required for optimal ECM formation and structure. Manganese and copper are also essential for collagen formation. Lysine, a natural inhibitor of plasmininduced proteolysis, contributes to ECM stability $(32,33)$. Green tea extract has been shown to control cancer cell growth, metastasis, angiogenesis, and other aspects of cancer progression (34-38). N-acetyl cysteine and selenium have been observed to inhibit MMP-9 activity and tumor invasion (39-41). Ascorbic acid was shown to inhibit cell division and growth through production of hydrogen peroxide (42). Arginine, a precursor of nitric oxide (NO), has been shown to predominantly act as an inducer of apoptosis, as in breast cancer cells (43).

In conclusion, our results show that cytokines and inhibitors regulate MMP-2 and MMP-9 expression in cervical and ovarian cancer cell lines HeLa, DoTc2-4510, and SK-OV-3, suggesting the clinical value of targeting these proteases for management of cervical and ovarian cancers and their pathogenesis.

\section{Acknowledgements}

The research study was funded by Dr Rath Health Foundation (Plantation, FL), a non-profit organization.

\section{References}

1. Cervical Cancer Statistics, http://www.cervicalcancer.org/ statistics.html, accessed 6/1/09.

2. American Cancer Society: What are the key statistics about cervical cancer? http://www.cancer.org/docroot/CRI/content/ CRI_2_4_1X_What_are_the_key_statistics_for_cervical_cancer_8 asp?rnav=cri accessed 6/1/09.

3. Ovarian Cancer National Alliance, Ovarian Cancer Statistics http://www.ovariancancer.org/about-ovarian-cancer/statistics/ accessed 10/19/09.

4. Fidler IJ: Molecular biology of cancer: invasion and metastasis In: Cancer: Principles and Practice of Oncology. 5th edition. De Vita VT, Hellman S, Rosenberg SA (eds). Lippincott-Raven, Philadelphia, pp135-152, 1997.

5. Liotta LA, Tryggvason K, Garbisa A, Hart I, Foltz CM and Shafie S: Metastatic potential correlates with enzymatic degradation of basement membrane collagen. Nature 284: 67-68, 1980.

6. Stetler-Stevenson WG: The role of matrix metalloproteinases in tumor invasion, metastasis and angiogenesis. Surg Oncol Clin N Am 10: 383-392, 2001

7. Cottam DW, Rennie IG, Woods K, Parsons MA, Bunning RA and Rees RC: Gelatinolytic metalloproteinase secretion patterns in ocular melanoma. Invest Ophthalmol Vis Sci 32: 1923-1927, 1992.

8. Fishman DA, Bafetti L, Banionis S, Kearns AS, Chilukuri K and Stack MS: Production of extracellular matrix degrading proteinases by primary cultures of human epithelial ovarian carcinoma cells. Cancer 80: 1457-1463, 1997.

9. Garzetti G, Ciavattini A, Lucarini G, Goteri G, de Nicolis M, Garbisa S, Masiero L, Romanini C and Graziella B: Tissue and serum metalloproteinase (MMP-2) expression in advanced ovarian serous cytstadenocarcinomas: clinical and prognostic implications. Anticancer Res 15: 2799-2804, 1995.

10. Gohji K, Fujomoto N, Hara I, Fujii A, Gotoh A, Okada H, Arakawa S, Kitazawa S, Miyake H, Kamidono S and Nakijima M: Serum matrix metalloproteinase- 2 and its density in men with prostate cancer as a new predictor of disease extension. Int $\mathrm{J}$ Cancer 79: 96-101, 1998.

11. Asha Nair S, Karunagaran D, Nair MB and Sudhakaran PR: Changes in matrix metalloproteinases and their endogenous inhibitors during tumor progression in the uterine cervix. J Cancer Res Clin Oncol 129: 123-131, 2003.

12. Zhou Cy, Yao JF and Chen XD: Expression of matrix metalloproteinase-2,9 and their inhibitor-TIMP 1,2 in human squamous cell carcinoma of uterine cervix. Al Zhen 21: 735-739, 2002. 
13. Lopata A, Agresta F, Quinn MA, Smith C, Ostor AG and Salamonsen LA: Detection of endometrial cancer by determination of matrix metalloproteinases in the uterine cavity. Gynecol Oncol 90: 318-324, 2003.

14. Torng PL, Mao TL. Chan WY, Huang SC and Lin CT: Prognostic significance of stromal metalloproteinase-2 in ovarian adenocarcinoma and in relation to carcinoma progression. Gynecol Oncol 92: 559-567, 2004

15. Stetler-Stevenson WG: Type IV collagenases in tumor invasion and metastasis. Cancer Metastasis Rev 9: 289-303, 1990.

16. Bérubé M, Deschambeault A, Boucher M, Germain L, Petitclerc E and Guérin SL: MMP-2 expression in uveal melanoma: differential activation status dictated by the cellular environment. Mol Vis 11: 1101-1111, 2005

17. Sato T, Sakai T, Noguchi Y, Takta M, Hirakawa S and Ito A: Tumor-stromal cell contact promotes invasion of human uterine cervical carcinoma cells by augmenting the expression and activation of stromal matrix metalloproteinases. Gynecol Oncol 92: 47-56, 2004.

18. Di Nezza LA, Misajon A, Zhang J, Jobling T, Quinn MA Ostör AG, Nie G, Lopata A and Salamonsen LA: Presence of active gelatinases in endometrial carcinoma and correlation of matrix metalloproteinase expression with increasing tumor grade and invasion. Cancer 94: 1466-1475, 2002.

19. Liotta LA and Kohn EC: The microenvironment of the tumorhost interface. Nature 411: 375-379, 2001

20. Pyke C, Kristensen P, Ralfkiaer E, Gröndahl-Hansen J, Eriksen J, Blasi $F$ and Danø $\mathrm{K}$ : Urokinase-type plasminogen activator is expressed in stromal cells and its receptor in cancer cells at invasive foci in human colon adenocarcinomas. Am J Pathol 138: 1059-1067, 1991

21. Harvey P, Clark IM, Jourand MC, Warn RM and Edwards DR: Hepatocyte growth factor/scatter factor enhances the invasion of mesothelioma cell lines and the expression of matrix metalloproteinases. Br J Cancer 83: 1147-1153, 2000.

22. Liu Z, Ivanoff A and Klominek J: Expression and activity of matrix metalloproteases in human malignant mesothelioma cell lines. Int J Cancer 91: 638-643, 2001.

23. Vincent MP, White LA and Schroen DJ: Regulating expression of the gene for matrix metalloproteinase-1 (collagenase) mechanisms that control enzyme activity, transcription and mRNA stability. Crit Rev Eukaryot Gene Expr 6: 391-411, 1996

24. Ray JM and Stetler-Stevenson WG: The role of matrix metalloproteinase and their inhibitors in tumour invasion, metastasis and angiogenesis. Eur Respir J 7: 2062-2072, 1994.

25. Apodaca G, Rutka JT, Bouhana K, Berens ME, Giblin JR, Rosenblum ML, McKerrow JH and Banda MJ: Expression of metalloproteinases and metalloproteinase inhibitors by fetal astrocytes and glioma cells. Cancer Res 50: 2322-2329, 1990.

26. Hazelbag S, Fleuren GJ, Baelde JJ, Schuuring E, Kenter GG and Gortar A: Cytokine profile of cervical cancer cells. Gynecol Oncol 83: 235-242, 2001

27. Nash MA, Ferrandina G, Gordinier M, Loercher A and Freedman RS: The role of cytokines in both the normal and malignant ovary. Endocr Relat Cancer 6: 93-107, 1999.

28. Davidson B, Goldberg J, Koplovic J, Lerner-Geva L, Gottlieb WH, Weiss B, Ben-Baruch G and Reich R: Expression of matrix metalloproteinase-9 in squamous cell carcinoma of the uterine cervix-clinico-pathologic study using immunohistochemistry and mRNA in situ haybridization. Gynecol Oncol 72: 380-386, 1999.
29. Roomi MW, Kalinovsky T, Roomi NW, Monterrey J, Rath M and Niedzwicki A: A nutrient mixure suppresses hepatic metastasis in athymic nude mice injected with murine B16FO melanoma cells. BioFactors 33: 181-189, 2008

30. Roomi MW, Ivanov V, Kalinovsky T, Niedzwiecki A and Rath M: Suppression of human cervical cancer clel lines Hela and DoTc2 4510 by a mixture of lysine, proline, ascrobic acid and green tea extract. Int J Gynecol Cancer 16: 1241-1247, 2006.

31. Roomi MW, Ivanov V, Kalinovsky T, Niedzwiecki A and Rath M: Inhibition of matrix metalloproteinase-2 secretion and invasion by human ovarian cancer cell line SK-OV-3 with lysine, proline, arginine, ascorbic acid and green tea extract. J Obstet Gynaecol Res 32: 148-154, 2006.

32. Rath M and Pauling L: Plasmin-induced proteolysis and the role of apoprotein(a), lysine and synthetic analogs. Orthomolecular Med 7: 17-23, 1992.

33. Sun Z, Chen YH, Wang P, Zhang J, Gurewich V, Zhang P and Liu JN: The blockage of high-affinity lysine binding sites of plasminogen by EACA significantly inhibits prourokinaseinduced plasminogen activation. Biochem Biophys Acta 1596: 182-192, 2002.

34. Valcic S, Timmermann BN, Alberts DS, Wachter GA, Krutzsch M, Wymer J and Guillen JM: Inhibitory effect of six green tea catechins and caffeine on the growth of four selected human tumor cell lines. Anticancer Drugs 7: 461-468, 1996.

35. Mukhtar H and Ahmed N: Tea polyphenols: prevention of cancer and optimizing health. Am J Clin Nutr 71: 1698s-1702s, 2000.

36. Yang GY, Liao J, Kim K, Yurtow EJ and Yang CS: Inhibition of growth and induction of apoptosis in human cancer cell lines by tea polyphenols. Carcinogenesis 19: 611-616, 1998.

37. Taniguchi S, Fujiki H, Kobayashi H, Go H, Miyado K, Sadano H and Shimikawa R: Effect of (-) epigallocatechin gallate, the main constituent of green tea, on lung metastasis with mouse B16 melanoma cell lines. Cancer Lett 65: 51-54, 1992.

38. Hare Y: Green Tea: Health Benefits and Applications. Marcel Dekker, New York, Basel, 2001

39. Kawakami S, Kageyama Y, Fujii, Kihara K and Oshima H: Inhibitory effects of $\mathrm{N}$-acetyl cysteine on invasion and MMP 9 production of T24 human bladder cancer cells. Anticancer Res 21: 213-219, 2001

40. Morini M, Cai T, Aluigi MG, Noonan DM, Masiello L, De Floro S, D'Agostinin F, Albini A and Fassima G: The role of the thiol $\mathrm{N}$-acetyl cysteine in the prevention of tumor invasion and angiogenesis. Int J Biol Markers 14: 268-271, 1999.

41. Yoon SO, Kim MM and Chung AS: Inhibitory effects of selenite on invasion of HT 1080 tumor cells. J Biol Chem 276: 20085-20092, 2001

42. Maramag C, Menon M, Balaji KC, Reddy PG and Laxmanan S: Effect of vitamin $\mathrm{C}$ on prostate cancer cells in vitro: effect on cell number, viability and DNA synthesis. Prostate 32: 188-195, 1997.

43. Cooke JP and Dzau VJ: Nitric oxide synthase: role in the genesis of vascular disease. Annu Rev Med 48: 489-509, 1997. 